\title{
KAJIAN YURIDIS TENTANG KEKUATAN PEMBUKTIAN PENDAPAT AHLI DALAM PROSES PEMERIKSAAN PIDANA (Studi Putusan Nomor : 863 / Pid. B / 2015 / PN Dps)
}

\author{
Riva'atul Azizah dan Nurbaedah \\ Fakultas Hukum Universitas Islam Kadiri \\ Email : fakultas.hukum@uniska-kediri.ac.id
}

Pembuktian tentang benar tidaknya terdakwa melakukan perbuatan yang didakwakan terhadap seseorang merupakan bagian terpenting dalam hukum acara pidana. Berkaitan dengan pembuktian maka saksi adalah orang yang mengetahui tentang suatu peristiwa pidana berdasarkan apa yang dilihat, didengar dan dialami sendiri. Namun alat bukti seperti kesaksian, menjadi kabur karena kesaksian hanya bisa diberikan oleh manusia yang mempunyai sifat pelupa, maka di butuhkan alat bukti lain seperti keterangan ahli. Isi keterangan seorang saksi dan ahli berbeda. Keterangan saksi ialah mengenai apa yang dialami oleh saksi itu sendiri sedangkan keterangan seorang ahli ialah penilaian mengenai hal-hal yang sudah nyata ada dan mengambil kesimpulan mengenai hal-hal itu. Keterangan ahli diperlukan dalam upaya untuk menanggulangi kejahatan yang dilakukan oleh seseorang dalam masyarakat karena terkadang para penegak hukum belum mampu mendapatkan hasil yang maksimal. Adapun rumusan masalah dalam penelitian ini adalah : (1) Bagaimana fungsi pendapat ahli dalam Bagaimanakah fungsi pendapat ahli dalam Perkara Nomor 863 / Pid. B / 2015 / PN Dps. (2) Bagaimanakah kekuatan pembuktian pendapat ahli dalam proses pemeriksaan pidana pada putusan Nomor 863 / Pid. B / 2015 / PN Dps. Sedangkan tujuan penelitian ini yaitu : (1) Untuk menganalisa fungsi pendapat ahli dalam Perkara 863 / Pid. B / 2015 / PN Dps. (2) Untuk menganalisa kekuatan pembuktian pendapat ahli dalam proses pemeriksaan pidana pada putusan Nomor 863 / Pid. B / 2015 / PN Dps. Adapun Jenis atau tipologi yang digunakan dalam penelitian ini adalah jenis penelitian hukum legal research yang mengacu pada norma-norma hukum yang terdapat dalam peraturan perundang-undangan dan putusan-putusan pengadilan serta norma-norma hukum yang ada dalam masyarakat, sedangkan metode pengumpulan data menggunakan studi kepustakaan ilmu hukum, jurnal hukum, laporan penelitian dan media online.

Kata Kunci : Pembuktian, Keterangan Ahli, putusan Nomor 863/Pid.B/2015/PN Dps 


\section{Pendahuluan}

Pemeriksaan suatu perkara pidana dalam suatu proses peradilan pada hakekatnya adalah bertujuan untuk mencari kebenaran materiil (materiilewaarheid) terhadap perkara tersebut. Hal ini dapat dilihat dari adanya berbagai usaha yang dilakukan oleh aparat penegak hukum dalam memperoleh bukti-bukti yang dibutuhkan untuk mengungkap suatu perkara baik pada tahap pemeriksaan pendahuluan seperti penyidikan dan penuntutan maupun pada tahap persidangan perkara tersebut.

Pembuktian tentang benar tidaknya terdakwa melakukan perbuatan yang didakwakan merupakan bagian yang terpenting dalam hukum acara pidana. Dalam hal ini pun hak asasi manusia dipertaruhkan. Sejarah perkembangan hukum acara pidana menunjukan bahwa ada beberapa sistem atau teori untuk membuktikan perbuatan yang didakwakan. Sistem atau teori pembuktian ini bervariasi menurut waktu dan tempat. ${ }^{1}$

Penilaian kekuatan pembuktian alat-alat bukti yang ada dikenal beberapa sistem atau teori pembuktian. Pertama pembuktian berdasarkan Undang-Undang secara positif, dimana jika telah terbukti suatu perbuatan sesuai dengan alat-alat bukti yang disebut oleh Undang-Undang maka keyakinan hakim sudah tidak diperlukan. Kedua pembuktian berdasarkan keyakinan hakim, dimana dalam menjatuhkan pidana dilakukan berdasarkan keyakinan hati nurani hakim itu sendiri tanpa disertai alat-alat bukti yang telah diatur dalam Undang-Undang. Ketiga pembuktian berdasarkan kayakinan hakim atas alasan yang logis, dimana hakim dapat memutuskan seseorang bersalah berdasarkan keyakinanya yang disertai dengan suatu kesimpulan dan berlandaskan pada peraturan pembuktian tertentu. Keempat pembuktian berdasarkan Undang-Undang secara negatif, Sistem pembuktian yang dianut oleh Indonesia yaitu hakim hanya boleh menjatuhkan hukuman dengan sekurang-kurangnya dua alat bukti dan satu keyakinan hakim, sistem ini sejalan dengan yang dianut dalam Pasal 183 KUHAP yang juga merupakan

${ }^{1}$ Hamzah Andi, Hukum Acara Pidana Indonesia, edisi revisi, Jakarta : Sinar Grafika, 2002, hlm. 245 
batas minimum pembuktian yang dijadikan patokan penerapan standar terbukti secara sah dan meyakinkan (beyond a reasonable doubt).

Berkaitan dengan pembuktian, maka saksi adalah orang yang mengetahui tentang suatu peristiwa pidana berdasarkan apa yang didengar sendiri, dilihat sendiri dan dialami sendiri dengan menyebut alasan dari pengetahuannya itu. Alat-alat bukti yang termuat dalam Undang-Undang sangat relatif. Alat bukti seperti kesaksian, bisa menjadi kabur karena kesaksian hanya bisa diberikan oleh manusia yang mempunyai sifat pelupa. Bahkan menurut psikologi, pemaparan satu peristiwa yang dilihat oleh beberapa orang akan berbeda-beda.

Keterangan saksi merupakan alat bukti di persidangan dan berguna dalam mengungkap duduk perkara suatu peristiwa pidana yang nantinya akan dijadikan salah satu dasar pertimbangan hakim untuk menentukan terbukti atau tidaknya perbuatan terdakwa serta kesalahan terdakwa. Dalam proses persidangan dikenal adanya beberapa macam saksi, misalnya dilihat dari pihak yang mengajukan dikenal sebutan: "saksi acharge" atau saksi yang memberatkan dan "saksi a decharge" atau saksi yang meringankan dan dilihat dari posisi dalam peristiwa tindak pidana dikenal sebutan : "saksi korban" atau saksi yang mengalami, "saksi melihat" dan "saksi mendengar". Jika keterangan tersebut berupa pendapat diberikan oleh seseorang yang memiliki keahlian tentang hal yang diperlukan untuk membuat terang suatu perkara pidana guna kepentingan pemeriksaan, maka hal tersebut dimasukkan sebagai alat bukti keterangan ahli. ${ }^{2}$

Sesuai dengan urutan alat bukti berdasarkan Pasal 184 KUHAP, maka setelah pemeriksaan para saksi selesai, sidang Pengadilan Negeri melakukan pemeriksaan "saksi ahli" yang diatur dalam Pasal 179, 180 KUHAP. $^{3}$ Keterangan ahli berbeda dengan keterangan saksi, tetapi sulit dibedakan.

2 AL. Wisnubroto, Praktek Peradilan Pidana Proses persidangan Perkara Pidana,: Jakarta : Galaxy Puspa Mega, 2002, hlm. 8

${ }^{3}$ Marpaung Leden, ProsesPenanganan Perkara Pidana (Di Kejaksaan \& Pengadilan Negeri Upaya Hukum dan Eksekusi), Bagian kedua, Jakarta : Sinar Grafika, 2010, hlm. 113 
Pasal 186 menyatakan bahwa keterangan seorang ahli ialah apa yang seorang ahli nyatakan disidang pengadilan. Jadi, keterangan tersebut diketahui bahwa yang dimaksud dengan keahlian ialah ilmu pengetahuan yang telah dipelajari (dimiliki) seseorang. Sehingga van Bemmelen mengatakan bahwa ilmu tulisan, ilmu senjata, pengetahuan tentang sidik jari dan sebagainya termasuk pengertian ilmu pengetahuan (wetenschap) menurut pengertian Pasal 343 Ned. Sv tersebut. Oleh karena itu, sebagai ahli seseorang dapat didengar keterangannya mengenai persoalan tertentu yang menurut pertimbangan hakim orang itu mengetahui bidang tersebut secara khusus. ${ }^{4}$

Keterangan ahli diperlukan dalam upaya untuk menanggulangi kejahatan yang dilakukan oleh seseorang dalam masyarakat karena terkadang para penegak hukum belum mampu mendapatkan hasil yang maksimal, misalnya dengan adaya kasus-kasus yang berkaitan dengan pemeriksaan kesehatan mental atau jiwa dari baik pelaku, saksi atau pihak-pihak yang berkepentingan dengan perkara tersebut tidak memberikan keterangan yang akurat. $^{5}$

Penanganan kasus pidana pembunuhan anak dengan korban Angeline pada tahun 2015 lalu banyak menggunakan pendapat ahli dalam penyelesaian persidangan. Terdakwa Margriet Kristina Megawe yang merupakan orang tua angkat Angeline terbukti melakukan pembunuhan berencana yang dibantu oleh Agustay Handa May yang merupakan pekerja rumah tangga di rumah Margriet. Berdasarkan kesaksian ahli gizi dr. Ida Bagus Putu Alit, Angeline meninggal dalam keadaan lambung kosong dan kurang gizi dimana hal ini melanggar Undang-Undang Nomor 35 Tahun 2014 tentang Perlidungan Anak. Akibat dari banyaknya perlakuan kejahatan terdakwa terhadap korban, Margriet dijatuhi pidana seumur hidup.

${ }^{4}$ Hamzah Andi, Hukum Acara Pidana Indonesia, edisi kedua, Sinar Grafika, 2014, hlm.

5 Emi Puasa Handayani dan Oktario, Keterangan Ahli Dalam Hukum Peradilan Pidana, Pena Kediri, 2009, hlm. 2 


\section{Rumusan Masalah}

2.1. Bagaimana fungsi pendapat ahli dalam Perkara Nomor 863 / Pid. B / 2015 / PN Dps.

2.2. Bagaimana kekuatan pembuktian pendapat ahli dalam proses pemeriksaan pidana pada putusan Nomor 863 / Pid. B / 2015 / PN Dps.

\section{Tujuan Penelitian}

3.1. Untuk menganalisa fungsi pendapat ahli dalam Perkara 863 / Pid. B / 2015 / PN Dps.

3.2. Untuk menganalisa kekuatan pembuktian pendapat ahli dalam proses pemeriksaan pidana pada putusan Nomor 863 / Pid. B / 2015 / PN Dps.

\section{Metode Penelitian}

\subsection{Jenis Penilitian}

Adapun jenis penelitian yang digunakan adalah legal research yang mengacu pada norma-norma hukum yang terdapat dalam peraturan perundang-undangan dan putusan-putusan pengadilan serta norma-norma hukum yang ada dalam masyarakat. ${ }^{6}$

4.2. Sumber Bahan Hukum

4.2.1. Bahan Hukum Primer

Bahan hukum primer diperoleh melalui bahan hukum yang mendasari penelitian ini yaitu Undang-Undang Dasar 1945, Kitab Undang-Undang Hukum Pidana, Kitab Undang-Undang Hukum Acara Pidana, Undang-Undang Nomor 35 tahun 2014 tentang Perlindungan Anak, Undang-Undang Nomor 11 Tahun 2012 tentang Sistem Peradilan Pidana Anak dan Putusan Mahkamah Agung.

\subsubsection{Bahan Hukum Skunder}

Bahan hukum skunder yaitu bahan hukum yang menunjang dan memberikan penjelasan mengenai data hukum primer, hal ini bisa

\footnotetext{
${ }^{6}$ Ali Zainudin, Metode Penelitian Hukum, Jakarta : Sinar Grafika, hlm.
} 
berupa studi kepustakaanilmu hukum, jurnal hukum, laporan penelitian, internet.

\subsubsection{Bahan Hukum Tersier}

Bahan hukum skunder yaitu bahan yang memberikan petunjuk maupun penjelasan terhadap data hukum primer dan data skunder, yang terdiri dari kamus bahasa indonesia maupun kamus hukum dan Ensiklopedia.

\subsection{Teknik Pengumpulan Data}

Dalam pengumpulan data untuk penelitian ini menggunakan metode kajian kepustakaan atau studi dokumenter.

\subsection{Analisis Data}

Analisis yang dilakukan adalah analisis data secara kualitatif yaitu bertujuan memahami, menginterpretasikan, mendeskripsikan suatu realitas. Ditarik suatu kesimpulan secara deduktif, yaitu menarik kesimpulan dari hal-hal yang bersifat khusus, dimana kedua fakta tersebut dijembatani oleh teori-teori.

\section{Hasil Penelitian dan Pembahasan}

\subsection{Fungsi Pendapat Ahli dalam Perkara Pembunuhan Berencana dan Eksploitasi Anak (Putusan Nomor 863 / Pid. B / 2015 / PN Dps)}

Hukum pembuktian merupakan salah satu bidang hukum yang cukup tua umurnya. Hal ini dikarena manusia dan masyarakat primitif pada hakikatnya memiliki rasa keadilan, di mana rasa keadilan tersebut akan tersentuh jika ada putusan hakim yang menghukum orang yang tidak bersalah, atau membebaskan orang yang bersalah, ataupun memenangkan orang yang tidak berhak dalam suatu persengketaan. Agar tidak sampai diputuskan secara keliru seperti itu, dalam suatu proses peradilan diperlukan pembuktian-pembuktian. Demikanlah dalam sejarah hukum berkembanglah satu set hukum dan kaidah di bidang pembuktian dari sistem pembuktian yang irasional dan sederhana ke arah sistem yang lebih rasional dan rumit. 
Pembahasan tentang hal-hal mengenai keterangan ahli adalah suatu gambaran akan pentingnya seorang ahli dalam memberikan keterangan tentang suatu tindak pidana berdasarkan kemampuan atau keahlian di bidangnya. Hal ini sangat dimungkinkan atas keterbatasan pengetahuan penyidik atau penuntut umum dan hakim dalam mengungkap suatu perkara tindak pidana tanpa keterangan ahli. Tanpa kehadiran seorang ahli dalam memberikan atau menjelaskan suatu masalah akan dapat dibayangkan bahwa penyidik akan mengalamai kesulitan dalam usaha mengungkap suatu tindak pidana, terutama tindak pidana berdimensi tinggi seperti tindak pidana teror dengan bom, pembakaran/kebakaran, pencemaran lingkungan, komputer, uang palsu, mutilasi, dll.

Perlunya bantuan seorang ahli dalam memberikan keterangan yang terkait dengan kemampuan dan keahliannya untuk membantu pengungkapan dan pemeriksaan suatu perkara pidana, A. Karim Nasution menyatakan :

"Meskipun pengetahuan, pendidikan dan pengalaman dari seseorang mungkin jauh lebih luas daripada orang lain, namun pengetahuan dan pengalaman setiap manusia tetap terbatas adanya. Maka oleh sebab itulah selalu ada kemungkinan bahwa ada soalsoal yang tidak dapat dipahami secukupnya oleh seorang penyidik dalam pemeriksaan pendahuluan ataupun seorang hakim di muka persidangan sehingga ia perlu diberi pertolongan oleh orang-orang yang memiliki suatu pengetahuan tertentu. Agar tugas-tugas menurut hukum acara pidana dapat dilaksanakan dengan sebaikbaiknya, maka oleh Undang-Undang diberi kemungkinan agar para penyidik dan para hakim dalam keadaan yang khusus dapat memperoleh bantuan dari orang-orang yang berpengetahuan dan berpengalaman khusus tersebut".

Syarat sahnya keterangan seorang ahli tidak diatur secara khusus dalam KUHAP, tetapi dapat dipikirkan bahwa berdasarkan Pasal 1 angka 28 KUHAP secara khusus ada dua syarat dari keterangan seorang ahli, ialah: 
5.1.1. Bahwa apa yang diterangkan haruslah mengenai segala sesuatu yang masuk dalam ruang lingkup kehaliannya.

5.1.2. Bahwa yang diterangkan mengenai keahliannya itu adalah berhubungan erat dengan perkara pidana yang sedang diperiksa. $^{7}$

Karena merupakan syarat, maka apabila ada keterangan seorang ahli yang tidak memenuhi salah satu syarat atau kedua syarat, maka keterangan ahli itu tidaklah berharga dan harus diabaikan. Kekuatan alat bukti keterangan ahli secara khusus adalah terletak pada syarat-syarat umum pembuktian dari alat-alat bukti lain terutama keterangan saksi (Pasal 179 ayat 2). Syarat umum dari kekuatan alat bukti termasuk keterangan saksi, yaitu:

5.1.1. Harus didukung atau bersesuaian dengan fakta-fakta yang didapat dari alat bukti lain. Sesuai dengan ketentuan Pasal 183 jo Pasal 185 ayat (2), maka satu-satunya alat bukti keterangan ahli tidaklah dapat digunakan sebagai dasar untuk membentuk keyakinan hakim. Kekuatan bukti keterangan ahli bukanlah sebagai tambahan bukti seperti saksi yang tidak disumpah sebagaimana saksi keluarga menurut Pasal 185 ayat 7 atau saksi anak dan saksi yang sakit ingatan (Pasal 171).

5.1.2. Keterangan ahli harus diatas sumpah sama dengan alat bukti keterangan saksi (Pasal 160 ayat 4 jo 179 ayat 2). Keterangan ahli yang diberikan di muka sidang tetap wajib disumpah, walaupun seorang ahli telah disumpah ketika ahli akan memberikan keterangan di tingkat penyidikan berdasarkan Pasal 120 ayat (2). Hal ini wajar karena menurut Pasal 185 keterangan ahli ialah apa yang seorang ahli nyatakan di sidang pengadilan. Oleh karena itu, sumpah di tingkat penyidikan adalah ditujukan hanya

\footnotetext{
${ }^{7}$ Prisco Jeheskiel Umboh, "Fungsi dan Manfaat Saksi Ahli..... Op. Cit, hlm 120
} 
untuk meletakkan kebenaran keterangan ahli yang diberikan di tingkat penyidikan saja.

Peningkatan fungsi dan kedudukan keterangan ahli menjadi alat bukti dapat diterima, mengingat perkembangan ilmu pengetahuan dan teknologi sekarang sangat pesat yang tidak mungkin hakim dapat menguasai semua bidang ilmu dan teknologi tersebut, sehingga wajar apabila sekarang hakim percaya dengan keterangan ahli. ${ }^{8}$

Keterangan ahli dibedakan menjadi 2 (dua) macam, yaitu (1) keterangan ahli secara lisan di muka sidang, dan (2) keterangan ahli secara tertulis diluar sidang. Keterangan ahli tertulis ini dituangkan dalam suatu surat yang menjadi alat bukti surat, seperti apa yang disebut visum et repertum (VER) yang diberikan pada tingkat penyidikan atas permintaan penyidik (Pasal 187 huruf c). ${ }^{9}$ Sedangkan keterangan ahli secara lisan di muka sidang di lakukan saat seorang ahli diminta oleh hakim untuk mengemukakan pendapatnya tentang suatu persoalan yang ditanyakan kepadanya tanpa melakukan suatu pemeriksaan. Dari sudut sifat isi keterangan yang diberikan ahli, maka ahli dapat dibedakan antara:

5.1.1. Ahli yang menerangkan tentang hasil pemeriksaan sesuatu yang telah dilakukannya berdasarkan keahlian khusus untuk itu. Misalnya, seorang dokter ahli forensik yang memberikan keterangan ahli di sidang pengadilan tentang penyebab kematian setelah dokter tersebut melakukan bedah mayat (otopsi). Atau seorang akuntan memberikan keterangan di sidang pengadilan tentang hasil audit yang dilakukannya atas keuangan suatu instansi pemerintah.

5.1.2. Ahli yang menerangkan semata-mata tentang keahlian khusus mengenai sesuatu hal yang berhubungan erat dengan perkara pidana yang sedang diperiksa tanpa melakukan pemeriksaan terlebih dulu. Misalnya, ahli dibidang perakit bom yang

\footnotetext{
${ }^{8}$ Prisco Jeheskiel Umboh, "Fungsi dan Manfaat Saksi Ahli..... Op. Cit, hlm 121

${ }^{9}$ Ibid., hlm 121
} 
menerangkan di dalam sidang pengadilan tentang cara merakit bom. Bahkan, dalam praktik, seorang ahli hukum bidang keahlian/kosentrasi khusus acapkali digunakan dan mereka juga disebut seorang ahli.

Berdasarkan ketentuan diatas, dapat dilihat fungsi keterangan ahli dalam Putusan Putusan Nomor 863 / Pid. B / 2015 / PN Dps (tentang pembunuhan berencana dan eksploitasi anak) sebagai:

5.1.1. Sebagai alat bukti keterangan dalam menjernihkan duduk persoalan yang timbul dalam suatu sidang dipengadilan. Setiap orang yang diminta pendapatnya sebagai ahli kedokteran kehakiman atau dokter atau ahli lainnya wajib memberikan keterangan ahli demi keadilan. Semua ketentuan tersebut diatas untuk saksi berlaku juga bagi mereka yang memberikan keterangan ahli, dengan ketentuan bahwa mereka mengucapkan sumpah atau janji akan memberikan keterangan yang sebaik-baiknya dan yang sebenarnya menurut pengetahuan dalam bidang keahliannya (Pasal 179 KUHAP). Dalam kasus ini, ada beberapa ahli yang dihadirkan dalam persidangan. Seperti ahli forensik, ahli gigi dan mulut, ahli psikologi forensik, ahli biologi dan kimia.

Ahli forensik memberikan hasil identifikasi dari korban antara lain meliputi : identitas mayat yang sebelumnya masih diragukan karena mayat di temukan dalam keadaan terkubur dan membusuk. Dengan hasil otopsi yang tertulis dalam Visum Et Repertum No : UK 01.15/IV.E/19/VER/281/2015, ahli forensik dapat mengetahui sebab kematian dan keadaan mayat semasa hidupnya.

Sedangkan identifikasi dari ahli gigi dan mulut memberikan hasil bahwa lepasnya 7 gigi rahang atas, 
diduga kekerasan tumpul dari arah depan yang di buktikan dengan patahnya tulang rahang atas kanan yang dikelilingi resapan darah.

5.1.2. Sebagai alat yang berguna untuk memberikan keterangan secara jelas mengenai suatu perkara pidana yang terjadi dengan menggunakan keahliannya atau pun dengan berdasarkan apa yang ia pahami atau tau mengenai suatu perkara pidana.

Keterangan ahli amat diperlukan dalam setiap tahapan pemeriksaan. Seperti dalam tahap penyidikan, tahap penuntutan maupun tahap pemeriksaan di sidang pengadilan. Dalam kaitanya dengan peranan para ahli yang terlibat untuk membantu menjernihkan suatu kasus perkara pidana, peranan ahli psikologi sangat berguna dalam kasus ini. Dengan hasil pemeriksaan ahli psikologi dan pengetahuan ahli dalam bidangnya, dapat diketahui bahwa terdakwa dalam kasus pembunuhan berencana dan eksploitasi anak pada putusan Nomor 863 / Pid. B / 2015 / PN Dps, memiliki jiwa psikopat. Kesimpulan yang di dapatkan dari hasil pemeriksaan ahli psikologi adalah bahwa terdakwa termasuk orang yang memiliki gangguan kepribadian ganda yang tidak dapat melakukan pengasuhan dengan baik bahkan cenderung menelantar korban. Terdakwa seringkali melakukan serangkaian tindak kekerasan terstruktur yang diyakininya sebagai tindakan yang benar.

5.1.3. Sebagai sebagai sarana saksi ahli dengan menggunakan keahliannya untuk memberikan keterangan demi membela korban.

Suatu kasus perkara tindak pidana akan jelas pokok persoalanya apabila pelaku meninggalkan bukti-bukti 
seperti : korban, bukti fisik maupu adanya saksi mata yang mengetahui. Keadaan akan menjadi sulit, saat di TKP hanya dijumpai bukti-bukti yang sangat minim atau sama sekali tidak ada. Disini keterangan ahli berperan menggunakan keahlianya untuk memberikan keterangan yang lebih jelas demi mencari kebenaran materiil. Dalam kasus pembunuhan berencana dan eksploitasi anak, keterangan dari beberapa ahli membantu mengungkapkan kebenaran. Seperti keterangan yang diberikan oleh seorang ahli yang membuat karya ilmiah publikasi di bidang hukum keperdataan. Ahli ini berpendapat bahwa :

"Pengangkatan anak pada prinsipnya adalah pengalihan kewajiban hukum dari orangtua kandung kepada orang tua angkatnya. Pengangkatan anak harus melihat pada tata cara atau hukum adat dimana anak diangkat. Di Indonesia sahnya pengangkatan anak harus berdasarkan penetapan pengadilan setelah salinan diserahkan ke Menteri Sosial yang satu ke cacatan sipil. Kesepakatan yang di tuangkan dalam suatu perjanjian di Notaris kembali kepada hakekatnya dari perjanjian tersebut. Pasal 1365 KUHPerdata menyatakan kesepakatan berlaku sebagai Undang-Undang bagi para bagi para pihak, artinya sesuai asas Pacta Sunt Servanda akan mempunyai daya ikat yang sempurna diantara para pihak yang membuat kesepakatan. Perbedaan dibuatnya akta antara orang tua asuh dan orang tua angkat adalah orang tua asuh berkewajiban untuk mengasuhhanya untuk mengasuh anak tersebut sedangkan orang tua angkat pengambilalihan kewajiban hukum sebelumnya di orang tua kandung ke orang tua angkat, orang tua asuh tidak mengalihkan kewajiban hukum dari orang tua kandung ke orang tua angkatnya hanya untuk mengasuh saja. BAP di Polda Bali dan di Polresta Denpasar ahli memang diperlihatkan akta yang di judulnya "Pengakuan Pengangkatan Anak", dilihat dari substansi dari akta tersebut menurut ahli belum sah, isinya/substansi hanya pada hak-hak dan kewajiban ketika telah diangkat menjadi anak angkat yang sah, seharusnya akta tersebut ditindaklanjuti ke Pengadilan untuk memperoleh Penetapan, menurut ahli bukan merupakan akta 
pengangkatan anak yang sah, menurut pemahaman ahli mengarah pada pengasuhan anak."

Ahli dari bidang kesehatan lingkungan juga mengungkapkan pendapat bahwa lingkungan yang ditempati oleh korban tidak memenuhi standar sebagai tempat pengasuhan anak. Fakta yang didapatkan ahli hampir di seluruh halaman, ruangan, kamar, lantai dan lorong terdapat sampah, kotoran binatang, barang-barang yang tidak terpelihara. Khusus untuk fisiologi rumah tidak menemukan adanya tempat bermain anak.

5.5.1. Berfungsi untuk menambahkan keyakinan hakim dalam memberikan suatu putusan atau keputusan didalam persidangan.

Keyakinan hakim menjadi hal yang sangat penting keberadaanya untuk proses lahirnya sebuah putusan. Mejelis hakim dalam mencari dan meletakan kebenaran yang akan dijatuhkanya dalam putusan, harus berdasarkan alat-alat bukti yang telah ditentukan dalam Pasal 184 KUHAP. Dari alat bukti yang ada majelis hakim menggunakan dasar moralitas dan logika hakim untuk menjatuhkan putusan. Dalam kasus ini, alat bukti ahli juga berperan sebagai salah satu hal yang mempengaruhi keyakinan hakim. Seperti yang tertera dalam amar putusan berikut :

"Menimbang, bahwa alasan tentang pendapat atau keterangan beberapa ahli yang diajukan dalam persidangan yang diragukan dan ditolak oleh Penasehat Hukum terdakwa, menurut Majelis tidaklah beralasan dan harus dikesampingkan oleh karena Majelis sangat yakin terhadap ahli baik dalam memberikan pendapat maupun dalam melaksanakan profesinya sudah barang tentu terikat oleh sumpah dan kode etik, sehingga Majelis apapun alasannya sepanjang tidak bisa dibuktikan sebaliknya tentang profesionalitas seorang 
ahli, tetap akan mendengar dan memperhatikan keterangan maupun pendapat ahli tersebut".

\subsection{Kekuatan Pembuktian Keterangan Ahli dalam Putusan Nomor 863 /} Pid. B / 2015 / PN Dps.

Menetapkan keterangan ahli sebagai alat bukti, memegang peran penting dalam menyelesaikan kasus pidana, seperti kasus pembunuhan dan eksploitasi anak yang di alami oleh Engeline. Beberapa alat bukti yang berkaitan dengan kemajuan teknologi informasi menjadikan sangat dibutuhkanya seorag ahli yang bisa meneliti kebenaran dari alat bukti tersebut dan hal ini sangatlah membantu proses persidangan.

Keterangan ahli pada umumnya tidak menyangkut pokok perkara pidana yang diperiksa. Sifatnya lebih ditujukan untuk menjelaskan sesuatu hal yang masih kurang terang atau jelas tentang sesuatu hal atau keadaan. Misalnya apakah korban meninggal karena dicekik atau di racun, tetapi keterangan ahli tidak dapat mengungkap siapa pelakunya. Jadi, apabila beberapa keterangan ahli hanya mengungkapkan suatu keadaan atau suatu hal yang sama sekalipun diberikan oleh beberapa ahli, tetapi dalam bidang keahlian yang sama maka berapa banyak pun keterangan ahli yang demikian tetap dianggap hanya bernilai satu alat bukti saja. Tetapi tanpa mengurangi pendapat itu, dalam keadaan tertentu keterangan beberapa orang ahli dapat dinilai sabagai dua atau beberapa alat bukti yang dapat dianggap memenuhi prinsip minimum pembuktian yang ditentukan oleh Pasal 183 KUHAP. ${ }^{10}$

Pada prinsipnya alat bukti keterangan ahli tidak mempunyai nilai kekuatan hukum yang mengikat dan memaksa bagi hakim. Dengan demikian nilai kekuatan pembuktian keterangan ahli sama halnya dengan nilai kekuatan pembuktian yang melekat pada alat bukti keterangan saksi. Oleh karena itu, nilai kekuatan pembuktian yang melekat pada alat bukti keterangan ahli yaitu :

\footnotetext{
${ }^{10}$ Harahap Yahya, 2006, Pembahasan Permasalahan......,Op. cit, hlm. 305
} 
5.2.1. Mempunyai nilai kekuatan pembuktian bebas atau vrijbewijskrachf. Di dalam dirinya tidak melekat nilai kekuatan pembuktianyang sempurna dan menentukan. Terserah pada penilaianhakim hakim bebas menilai dan tidak terikat kepadanya. Tidak ada keharusan bagi hakim untuk harus menerimakebenaran keterangan ahli dimaksud. Hakim dalam menggunakan wewenang kebenaran dalam penilaian pembuktian, harus benar-benar bertanggungjawab atas landasan moral dan kebenaran sejati demi tegaknya hukum serta kepastian hukum.

5.2.2. Sesuai dengan prinsip minimum pembuktian yang diatur dalam Pasal 183, keterangan ahli yang berdiri sendiri saja tanpa didukung oleh salah satu alat bukti yang lain, tidak cukup dan tidak memadai untuk membuktikan kesalahan terdakwa. Jika Pasal 183 KUHAP dihubungkan dengan ketentuan Pasal 185 ayat (2) yang menegaskan seorang saksi saja tidak cukup membuktikan kesalahan terdakwa, prinsip ini juga berlaku untuk alat bukti keterangan ahli. Bahwa keterangan seorang ahli saja tidak cukup membuktikan kesalahan terdakwa. Oleh karena itu agar keterangan ahli dapat dianggap cukup membuktikan kesalahan terdakwa harus disertai dengan alat bukti lain.

Keterangan ahli dalam Putusan Putusan Nomor 863 / Pid. B / 2015 / PN Dps memiliki nilai kekuatan pembuktian bebas (vrij Bewijs Kracht). Dalam keterangan ahli tidak melekat nilai kekuatanpembuktian yang sempurna dan menentukan, sehingga penggunaanketerangan ahli terserah pada penilaian hukum hakim dalam persidangan. Tidak ada keharusan bagi hakim untuk menerima kebenaran keterangan ahli. 
Pada sidang kasus pembunuhan Engeline, penyidik telah meminta keterangan seorang ahli yang dituangkan dalam BAP, namun dalam persidangan hakim juga mendengar langsung keterangan dari ahli di muka sidang. Putusan Nomor 863 / Pid. B / 2015 / PN Dps didalamnya menyebutkan mengenai isi dari keterangan ahli, yaitu mengenai penyebab kematian korban.

Keterangan ahli yang dihadirkan di persidangan dalam Putusan Nomor 863 / Pid. B / 2015 / PN Dps mempunyai kekuatan pembuktian karena merupakan alat bukti yang sah dan bersesuaian dengan alat bukti lain yaitu alat bukti keterangan saksi dan alat bukti surat. Sehingga hakim dapat menerimanya dan dipergunakan sebagai bahan pertimbangan hukum bagi hakim dalam menjatuhkan putusan pidana terhadap terdakwa.

\section{Kesimpulan}

6.1. Fungsi pendapat ahli dalam Putusan Nomor 863 / Pid. B / 2015 / PN Dps adalah sebagai alat bukti keterangan dalam menjernihkan duduk persoalan yang timbul dalam suatu sidang dipengadilan, sebagai alat yang berguna untuk memberikan keterangan secara jelas mengenai suatu perkara pidana yang terjadi dengan menggunakan keahliannya atau pun dengan berdasarkan apa yang ia pahami atau tau mengenai suatu perkara pidana, sebagai sarana saksi ahli dengan menggunakan keahliannya untuk memberikan keterangan demi membela korban serta berfungsi untuk menambahkan keyakinan hakim dalam memberikan suatu putusan atau keputusan didalam persidangan.

6.2. Sehubungan dengan kekuatan pembuktian keterangan ahli dalam Putusan Nomor 863 / Pid. B / 2015 / PN Dps adalah alat bukti keterangan ahli yang dihadirkan dipersidangan merupakan alat bukti yang sah dan mempunyai kekuatan pembuktian bebas. Karena alat bukti keterangan ahli yang di hadirkan sudah memenuhi syarat formil dan materiil. 


\section{DAFTAR PUSTAKA}

\section{Peraturan Perundang-undangan}

Undang-Undang Nomor 8 Tahun 1981, Lembaran Negara Tahun 1981 Nomor 76 Tambahan Lembaran Negara Nomor 3209 tentang Kitab UndangUndang Hukum Acara Pidana.

Undang-Undang Nomor 35 Tahun 2014 tentang Perlindungan Anak.

\section{Literatur Ilmiah}

AL. Wisnubroto, Praktek Peradilan Pidana Proses persidangan Perkara Pidana, Jakarta : Galaxy Puspa Mega, 2002.

Hamzah Andi, Hukum Acara Pidana Indonesia, edisi revisi, Jakarta : Sinar Grafika, 2002.

------------, Hukum Acara Pidana Indonesia. edisi kedua, Jakarta : Sinar Grafika, 2014.

Marpaung Leden, ProsesPenanganan Perkara Pidana (Di Kejaksaan \& Pengadilan Negeri Upaya Hukum dan Eksekusi). edisi kedua, Jakarta : Sinar Grafika, 2010.

Puasa Handayani Emi \& Oktario, Keterangan Ahli Dalam Hukum Peradilan Pidana, Pena Kediri, 2009.

Ali Zainudin, Metode Penelitian Hukum, Jakarta : Sinar Grafika.

Prisco Jeheskiel Umboh, "Fungsi dan Manfaat Saksi Ahli Memberikan Keterangan Dalam Proses Perkara Pidana", Lex Crimen, Vol. 2 No. 2, 2013.

Yahya Harahap, M, Pembahasan Permasalahan dan Penerapan KUHAP Penyidikan dan Penuntutan, Jakarta : Sinar Grafika, 2006. 